\title{
Influence of Crop Management on Take-All Development and Disease Cycles on Winter Wheat
}

\author{
Nathalie Colbach, Philippe Lucas, and Jean-Marc Meynard
}

First author: URI-GC, INRA, BP 29, 35650 Le Rheu, France; second author: Station de Pathologie Végétale, INRA, BP 29, 35650 Le Rheu, France; and third author: Laboratoire d'Agronomie, INRA-INAPG, Centre de Grignon, 78850 Thiverval-Grignon, France. Current address of N. Colbach: Station d'Agronomie, INRA, 17 rue Sully, BV 1540, 21034 Dijon Cedex, France. Accepted for publication 18 September 1996.

\section{ABSTRACT}

Colbach, N., Lucas, P., and Meynard, J.-M. 1997. Influence of crop management on take-all development and disease cycles on winter wheat. Phytopathology 87:26-32.

Wheat was assessed at four crop growth stages for take-all (Gaeumannomyces graminis var. tritici) in a series of field trials that studied the effects of five wheat management practices: sowing date, plant density, nitrogen fertilizer dose and form, and removal/burial of cereal straw. An equation expressing disease level as a function of degree days was fitted to the observed disease levels. This equation was based on take-all epidemiology and depended on two parameters reflecting the importance of the primary and secondary infection cycles, respectively. Early sowing always increased disease frequency via primary infection cycle; its influ- ence on the secondary cycle was variable. Primary infection and earliness of disease onset were increased by high density; however, at midseason take-all was positively correlated to the root number per plant, which was itself negatively correlated to plant density. At late stages of development, neither plant density nor root number per plant had any influence on disease. A high nitrogen dose increased both take-all on seminal roots and severity of primary infection cycle but decreased takeall on nodal roots and secondary infection cycle. Ammonium (versus ammonium nitrate) fertilizer always decreased disease levels and infection cycles, whereas straw treatment (burial versus removal of straw from the previous cereal crop) had no influence.

Additional keywords: disease progress model.
The take-all fungus, Gaeumannomyces graminis (Sacc.) Arx \& D. Olivier var. tritici J. Walker, infects the roots of most winter cereals, reducing water and nutrient absorption. This disease, therefore, can be responsible for important yield losses $(1,17,23,31,39)$. Because no effective chemical control exists to limit take-all, there is a need to know the effect of cropping practices on this disease to limit yield reductions in the absence of chemical control. Crop rotation has a major influence on the disease, and the fungus is reported to survive on former host crop residues $(5,6,9,40,41,42)$. The relative importance of other cultural practices is not as well understood.

Most works based on sample survey $(1,29)$ or field trials $(16,25$, 43) have been published without providing a time course of infection or disease development. Disease progress has been partially studied by other authors $(3,11)$ with the help of equations based on epidemiological knowledge but without taking into account the influence of crop management on various infection mechanisms.

In this paper, we present the results from field trials that were assessed for take-all at several wheat growth stages. We analyze disease incidence both separately at each crop growth stage and as a function of time to (i) determine the influence of crop management practices during take-all development and (ii) establish a hierarchy of the relative importance of each of these cultural control practices.

\section{MATERIAL AND METHODS}

Experimental plan. Winter wheat was assessed visually for take-all in four multifactorial field trials combining five cultural practices (Table 1): sowing date, plant density, nitrogen fertilizer dose and form, and removal/burial of cereal straw. These practices were tested in three locations in France (Le Rheu, La Verrière, and

Corresponding author: N. Colbach; E-mail address: colbach@dijon.inra.fr

Publication no. P-1996-1104-01R

(C) 1997 The American Phytopathological Society
Chartres) in 1991 to 1992 and again in Le Rheu in 1992 to 1993 that were chosen to provide a combination of different pedological and climatic conditions (Table 2). To maximize disease risk, the crops preceding the experiment were either winter wheat or winter barley, which are both host plants for take-all (28). In two trials, Le Rheu 1992 and 1993, the crops preceding the previous crop also were wheat or barley, whereas they were nonhosts in the two other sites (potato in La Verrière and maize in Chartres).

For each cultural practice, two levels were chosen (Table 1): sowing date (early versus late), sowing density (high versus low), total nitrogen dose (high versus low), nitrogen fertilizer form (low versus high ammonium content), and removal/burial of straw originating from the previous crop. Most practices were arranged factorially, except for the combinations of low nitrogen dose and buried straw and of high ammonium nitrogen and removed straw. In the La Verrière location, no high ammonium nitrogen was used, but the low nitrogen and buried straw combination was included. Thus, there were always 16 combinations of experimental factors. At three locations (Le Rheu 1992, Le Rheu 1993, and Chartres), a balanced 4-block design was used, and every field was composed of 64 plots; at La Verrière, the design was composed only of 3 blocks and 48 plots. Each plot was $60 \mathrm{~m}^{2}$.

Cultural practices applied uniformly to all plots were as follows. The take-all susceptible wheat cv. Soissons was used in each experiment. The fields were plowed and harrowed the day before or on the day of sowing, and a herbicide was sprayed the day after and again during the spring. No fungicides were applied for foot diseases (eyespot due to Pseudocercosporella herpotrichoides), but foliar diseases that usually occurred in the areas of experimentation (Septoria diseases and rusts) were controlled with fungicide applications at heading.

The number of plants per square meter was determined at plant emergence; the numbers of seminal (only for the first two assessment stages) and nodal roots per plant were counted at each assessment stage. 
Disease assessment. Every plot was visually assessed for takeall at growth stages $15,30,50$, and 80 according to the $\mathrm{Za}$ doks scales (44). Eight plants were sampled from each of four randomly chosen subplots that measured $25 \mathrm{~cm} \times 2$ rows. At stages 15 and 30 , the percentage of diseased plants was determined, and the incidence of take-all on seminal and nodal roots was distinguished. After stage 30, seminal roots were no longer assessed.

Soil conduciveness. Soil conduciveness to take-all was assessed at the three locations in 1992. This method (24) consists of measuring take-all severity on growth chamber-grown plants after the soils have been amended with different rates of artificial inoculum $(0,0.25,0.825$, and $2.5 \mathrm{~g}$ of $G$. graminis propagules per $\mathrm{kg}$ of soil). After 35 days of growth in a climatic chamber $\left(12\right.$ to $16^{\circ} \mathrm{C}$, 16-h photoperiod, and 70 to $90 \%$ relative humidity), plants were pulled out, and the necrosed root length per plant was calculated for each soil and rate of added inoculum.

Statistical analysis. To analyze take-all levels for each root system at each stage and location, the general linear model (GLM procedure) of SAS software (35) was used. Several models were analyzed. The first of these used disease incidence as the dependent variable and the experimental factors as independent variables: percentage of diseased plants $=$ constant + sowing date + plant density + nitrogen dose + nitrogen form + straw treatment + block + assessor + sowing date-plant density interaction + sowing date-nitrogen dose interaction + sowing date-nitrogen form interaction + sowing date-straw treatment interaction + error

Plant density was treated as a quantitative variable, and all other independent variables were treated as qualitative variables. Only the interactions between sowing date and the other practices were analyzed to keep the models as simple as possible. Effects of nitrogen dose and form were used only in models corresponding to those crop growth stages that were subsequent to the first fertilizer application (stage 30 at La Verrière and Le Rheu in 1992 and 1993 and stage 50 for Chartres, where nitrogen dose and form did not differ at the first application). To study the influence of the architecture of the root system, the number of roots per plant was added as a covariable to model 1 . An assessor effect was introduced into the models to take into account the possible variations due to different persons assessing disease levels.

The final models contained only those factors and covariables for which the significance of the regression parameter estimate associated with the factor was $P<0.05$. The sum of squares used to calculate the $P$ value for each factor or covariable was adjusted

TABLE 1. Cultural practices evaluated for management of take-all of wheat, conducted in France during 1991 to 1993

\begin{tabular}{|c|c|c|c|c|c|}
\hline \multirow[b]{2}{*}{ Treatment } & \multirow[b]{2}{*}{ Level } & \multicolumn{4}{|c|}{ Experimental site } \\
\hline & & Le Rheu 1992 & Le Rheu 1993 & La Verrière 1992 & Chartres 1992 \\
\hline \multirow[t]{2}{*}{ Sowing date } & Early & 17 October & 16 October & 11 October & 8 October \\
\hline & Late & 26 November & 24 November & 6 November & 7 November \\
\hline \multirow[t]{2}{*}{ Plant density ${ }^{\mathrm{w}}$ (plants $/ \mathrm{m}^{2}$ ) } & High & 231 & $194 / 108^{x}$ & 236 & 228 \\
\hline & Low & 140 & $138 / 74^{x}$ & 70 & 179 \\
\hline \multirow[t]{2}{*}{ Total available nitrogen $(\mathrm{kg} / \mathrm{ha})^{\mathrm{y}}$} & High & 325 & 325 & 380 & 290 \\
\hline & Low & 235 & 230 & 300 & 200 \\
\hline \multirow[t]{2}{*}{ Nitrogen form (ammonium content) } & High & Ammonium sulfate & Ammonium sulfate & None & Urea + ammonium sulfate \\
\hline & Low & Ammonium nitrate & Ammonium nitrate & Ammonium nitrate & Ammonium nitrate \\
\hline \multirow{2}{*}{ Straw treatment } & & Buried & Buried & Buried & Buried \\
\hline & & Removed $^{\mathrm{z}}$ & Removed & Removed & Removed \\
\hline
\end{tabular}

${ }^{\text {w }}$ Seed depth was 2 to $3 \mathrm{~cm}$, and row spacing was $16 \mathrm{~cm}$.

$x$ The first density was observed on early sown plots; the second density was observed on late sown plots.

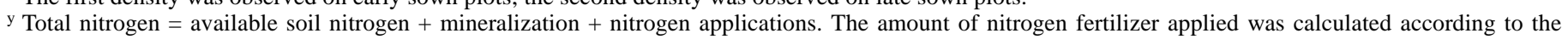
predictive balance sheet method (32). Nitrogen fertilizer was applied as top dressing twice during the season at growth stages 15 and 30.

z Straw was baled (Le Rheu 1992 and 1993, and Chartres 1992) or burnt (La Verrière 1992).

TABLE 2. Description of the experiment sites used to evaluate cultural practices for management of take-all of wheat in experiments conducted in France during 1991 to 1993

\begin{tabular}{|c|c|c|c|c|c|c|c|c|c|c|c|c|}
\hline \multirow{2}{*}{$\begin{array}{l}\text { Experiment } \\
\text { site }\end{array}$} & \multirow[b]{2}{*}{ Longitude } & \multirow[b]{2}{*}{ Latitude } & \multirow[b]{2}{*}{ Altitude } & \multicolumn{3}{|c|}{ Soil texture } & \multicolumn{3}{|c|}{ Mean annual temperature (C) } & \multicolumn{3}{|c|}{ Mean annual precipitation (mm) } \\
\hline & & & & Loam (\%) & Silt (\%) & $\overline{\text { Sand }(\%)}$ & Mean $^{y}$ & $1991-1992^{z}$ & $1992-1993^{z}$ & $\overline{\text { Mean }^{y}}$ & $1991-1992^{z}$ & $1992-1993^{z}$ \\
\hline Char & $1^{\circ} 31^{\prime}$ & $48^{\circ} 28^{\prime}$ & $156 \mathrm{~m}$ & $22-24$ & $66-68$ & 5 & 10.3 & 10.8 & & 58 & 340 & \\
\hline Le Rheu & $1^{\circ} 43^{\prime}$ & $48^{\circ} 01^{\prime}$ & $34 \mathrm{~m}$ & 15 & 70 & 15 & 10.2 & 11.6 & 11.5 & 714 & 616 & 675 \\
\hline
\end{tabular}

y Mean over 30 years.

z Annual means for 1991 to 1992 and 1992 to 1993 were calculated from August 1991 to July 1992 and from August 1992 to July 1993 , respectively.

TABLE 3. Mean incidence and severity of take-all on nodal roots of wheat grown at three locations in France

\begin{tabular}{|c|c|c|c|c|c|c|c|c|}
\hline \multirow[b]{3}{*}{ Growth stage $^{w}$} & \multicolumn{8}{|c|}{ Experiment site ${ }^{\mathrm{x}}$} \\
\hline & \multicolumn{2}{|c|}{ Le Rheu 1992} & \multicolumn{2}{|c|}{ Le Rheu 1993} & \multicolumn{2}{|c|}{ La Verrière 1992} & \multicolumn{2}{|c|}{ Chartres 1992} \\
\hline & Incidence ${ }^{y}$ & Severity ${ }^{z}$ & Incidence & Severity & Incidence & Severity & Incidence & Severity \\
\hline 15 & 0 & & 3 & & 0 & & 0 & \\
\hline 30 & 16 & 5 & 10 & 3 & 3 & 0.3 & 0 & 0 \\
\hline 50 & 39 & 8 & 46 & 47 & 6 & 12 & 3 & 0.1 \\
\hline 80 & 66 & 90 & 63 & 176 & 61 & 86 & 1 & 0.1 \\
\hline
\end{tabular}

w Decimal wheat growth stage according to Zadoks et al. (44).

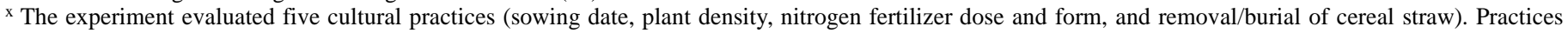
were arranged factorially, except for the combinations of low nitrogen dose and buried straw and high ammonium nitrogen and removed straw. In La Verrière, no high ammonium nitrogen was used, but the low nitrogen-buried straw combination was included.

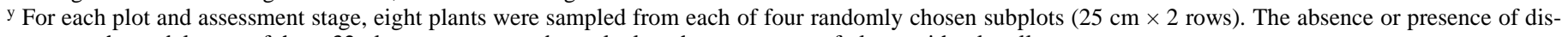
ease on the nodal roots of these 32 plants was assessed to calculate the percentage of plants with take-all.

${ }^{\mathrm{z}}$ Disease severity was estimated by summing the length of nodal roots (millimeters) with take-all symptoms for the 32 plants. 
to all terms present in the model and did not depend on their order of appearance in the model (i.e., the type III sum of squares of the GLM procedure).

Disease progress model. A kinetic equation similar to one presented by Brassett and Gilligan (3) was used to describe the number of infected roots as a function of primary and secondary inoculum. We considered primary inoculum $(p)$ to arise from host residues close to the soil surface and secondary inoculum as infectious disease symptoms on living plants. Because we were unable to distinguish between infectious and noninfectious symptoms, all plants with visible take-all $(i)$ were considered potential producers of secondary inoculum. Each inoculum type was assigned an infection rate: $k_{1}$ was associated with the primary in-

TABLE 4. Take-all severity on wheat grown in a greenhouse in soils from three locations in France and amended with increasing densities of Gaeumannomyces graminis var. tritici

\begin{tabular}{lcccc}
\hline & \multicolumn{4}{c}{ G. graminis var. tritici propagules/kg of soil ${ }^{\mathrm{z}}$} \\
\cline { 2 - 5 } Experiment site & $0 \mathrm{~g}$ & $0.25 \mathrm{~g}$ & $0.825 \mathrm{~g}$ & $2.5 \mathrm{~g}$ \\
\hline Le Rheu & $14.99 \mathrm{a}$ & $11.33 \mathrm{a}$ & $36.15 \mathrm{a}$ & $29.29 \mathrm{a}$ \\
La Verrière & $2.25 \mathrm{ab}$ & $6.59 \mathrm{a}$ & $30.80 \mathrm{ab}$ & $31.15 \mathrm{a}$ \\
Chartres & $0.47 \mathrm{~b}$ & $11.3 \mathrm{a}$ & $15.07 \mathrm{~b}$ & $27.25 \mathrm{a}$ \\
\hline
\end{tabular}

${ }^{\mathrm{z}}$ Disease severity was estimated by summing necrosed root length at 35 days after planting. Means within a column followed by the same letter are not significantly different at $P<0.05$ according to Fisher's protected least significant difference test. fection cycle and $k_{2}$ was associated with the secondary infection. These rates were assumed to be constant with time. If $i$ is the number of diseased plants, then $n-i$ is the number of healthy plants, where $n$ is the total number of plants. The rate of disease increase, i.e., the variation of diseased plants per degree day, was expressed as

$$
d i / d t=\left(k_{1} p+k_{2} i\right)(n-i)
$$

To model the percentage of diseased plants $(y)$, equation 2 was divided by the number of plants $(n)$, which assumes no plant loss during winter or due to disease. We further defined $c_{1}=k_{1} p$ and $c_{2}=k_{2} n$, which gave the following equation:

$$
d y / d t=\left(c_{1}+c_{2}\right)(1-y)
$$

This equation integrates to

$$
y=\frac{1-e^{-\left(c_{1}+c_{2}\right) t}}{1+\left(c_{2} / c_{1}\right) e^{-\left(c_{1}+c_{2}\right) t}}
$$

where time $t$ is expressed as cumulative degree days (basis $0^{\circ} \mathrm{C}$ ) since sowing. At sowing $(t=0)$, there are no diseased plants $(y=$ $0)$; therefore, the constant of integration is assumed to be nil.

Assessing disease incidence at only four stages in the field trials provided insufficient data to judge equation 4 . Therefore, this equation was evaluated first on a plot at Le Rheu, which was assessed every 2 weeks after stage 30 . For this evaluation, wheat was sown on 16 October 1992 at 225 grains per $\mathrm{m}^{2}$; no nitrogen fertilizer was applied.

TABLE 5. Regression estimates ${ }^{s}$ for the effect of wheat cultural practices on the percentage of plants with take-all in France

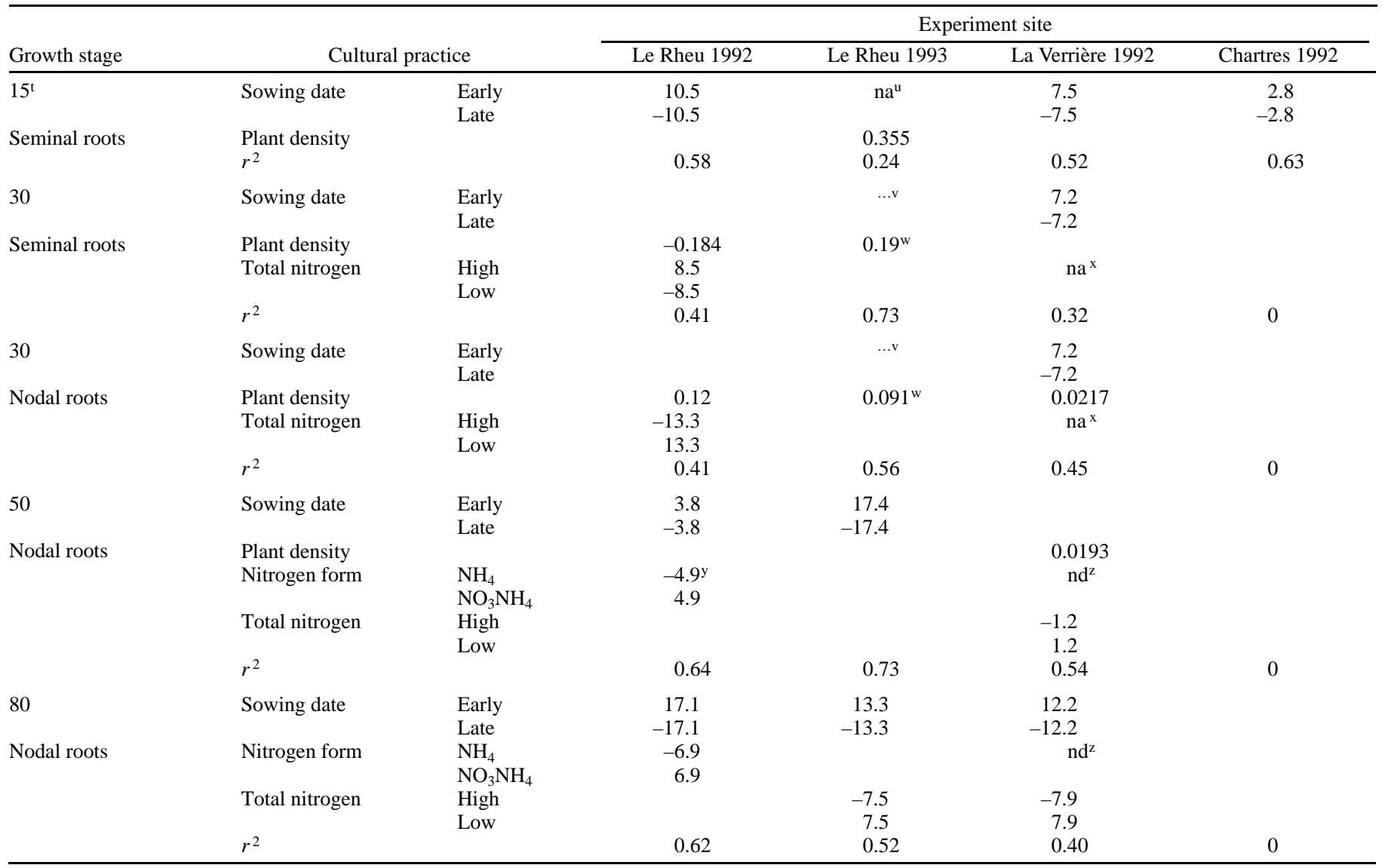

${ }^{\mathrm{s}}$ Estimates are for model 1 (described in text); effects of assessor and block on disease are not shown.

${ }^{\mathrm{t}}$ Decimal growth stage of wheat on the Zadoks scale (44).

${ }^{u}$ Late sown plots were not assessed at this stage (na $=$ not assessed).

v The sowing date-plant density interaction is significant at $P=0.0001$.

${ }^{\text {w }}$ The sowing date-plant density interaction is significant at $P=0.0001$. The number is the correlation of plant density with disease in early sown plots.

${ }^{x}$ Plots with low nitrogen were not assessed at this stage.

y This effect is only significant at $P=0.1$, but without its presence, no significant model would be possible.

${ }^{\mathrm{z}}$ There were no plots with $\mathrm{NH}_{4}$ on this site (nd = not determined). 
After this preliminary test, parameters $c_{1}$ and $c_{2}$ of equation 4 were estimated for every experimental treatment at each site. We used the iterative nonlinear model procedure of SAS (NLIN [35]) for this purpose. The fit of the model to the data was based on minimization of square sums weighted by the inverse of the variance corresponding to each assessment stage.

Take-all risk model. For each of the sets of estimates of $c_{1}$ and $c_{2}$, we evaluated a linear analysis of covariance model to interpret the parameter value for each site as a function of the various factors and covariables used in model 1 . The initial model was as follows:

parameter value $=$ constant + sowing date + plant density + nitrogen dose + nitrogen form + straw treatment + block + assessor + sowing date-plant density interaction + sowing date-nitrogen dose interaction + sowing date-nitrogen form interaction + sowing date-straw treatment interaction + error

The model contained neither assessor nor block effects, because we had only one set of parameters for each experimental treatment. Because of this low degree of freedom, we chose $P<0.1$ as the threshold value on which to reject the null hypothesis. As before, the final model contained only the statistically significant factors and covariables. If the condition of variance homogeneity necessary to apply a linear model was not fulfilled, the Box-Cox (2) transformation was used to homogenize variance. For example, if the linear regression of $1 \mathrm{n}$ [variance(parameter)] $=a+b \ln$ (parameter) was significant, parameter $c_{i}$ was transformed as follows:

$$
c_{\text {transformed }}=c^{1-b / 2}
$$

The parameter variances were those estimated by the NLIN procedure simultaneously with parameter estimates.

\section{RESULTS}

Effects of cultural practices. Le Rheu 1992 was the experimental site with the highest final amount of disease, followed by Le Rheu 1993 and La Verrière (Table 3). Infection at Chartres was nearly nil. There was no significant difference in soil conduciveness for take-all between Le Rheu 1992 and La Verrière (Table 4), despite the slow disease onset observed at the latter site (Table 3). Soil conduciveness was much lower at Chartres. Natural inoculum density of soil appeared to be higher at Le Rheu 1992 than at La Verrière or Chartres, because the potted plants were the most severely diseased in soil from Le Rheu 1992 without additional artificial take-all inoculum.

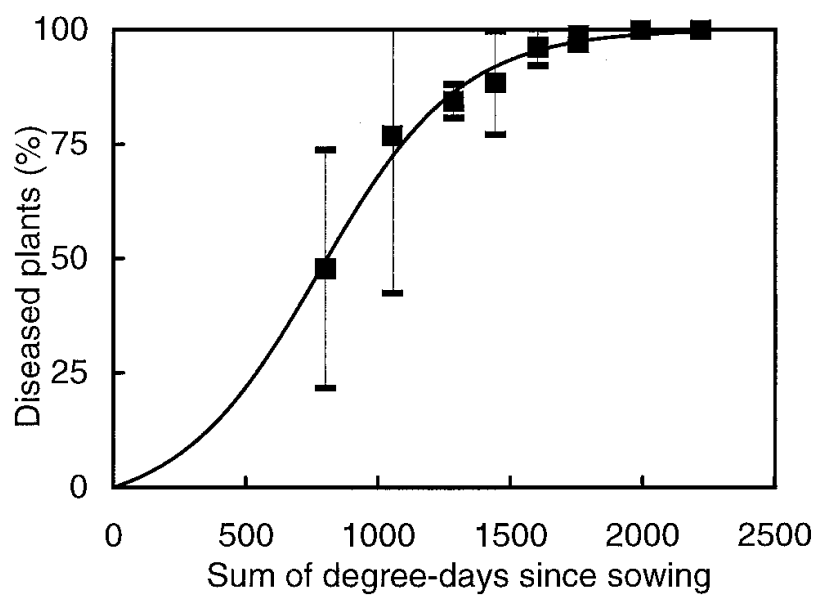

Fig 1. Take-all disease progress as a function of cumulative degree days since sowing of wheat in Le Rheu, France, in 1993. Data points are the mean and standard error of five observations. The line was fit to the data as described in text.
Early sowing always increased take-all on both seminal and nodal roots (Table 5), except at very low incidences of disease (nodal roots at Chartres). The effect of plant density was not as important as early sowing (Table 5), and the density effect usually only became significant when disease incidence increased, but was again insignificant at the last stages. An increase in plant density always resulted in a disease increase, except for take-all on seminal roots at stage 30 in Le Rheu 1992. If the covariable root number per plant was added to the GLM model, a positive correlation of root number with disease incidence was significant on several sites at stage 30 (data not shown). At late stages of wheat growth, a high rate of nitrogen fertilizer increased take-all on seminal roots and always decreased it on nodal roots (Table 5). The form of nitrogen fertilizer also influenced disease, with more severe disease in plots fertilized with ammonium nitrate compared with ammonium sulfate (Table 5). Burying versus baling straw did not differentially influence infection frequency.

Disease progress model. Evaluation of the disease progress equation on the frequently assessed plot showed that the chosen equation was well suited to describe increase of take-all over time (Fig. 1). For the take-all management experiments, the precision with which the disease progress equation described the data strongly depended on the mean disease incidence at each site. Precision was highest and least variable for Le Rheu 1992 (mean $r^{2}=$ 0.95 , standard error $[\mathrm{SE}]=0.05$ ) and lowest and most variable for Chartres (mean $r^{2}=0.45, \mathrm{SE}=0.29$ ). Regression estimates of $c_{1}$ and $c_{2}$ were not significantly different from 0 for one treatment at La Verrière and for three at Chartres. Based on estimates of $c_{1}$, Le Rheu 1992 and 1993, which were the only sites where the two preceding crops were hosts, were apparently most favorable for primary infection (Table 6). At Chartres and La Verrière, estimates of $c_{1}$ were very low. The difference in amount of disease at Chartres compared with the three other sites was even more noticeable for parameter $c_{2}$ (Table 6). Le Rheu 1992 and La Verrière had the highest estimated values of the $c_{2}$ parameter.

Early sowing date always increased $c_{1}$ (Table 7), whereas an effect of sowing date on $c_{2}$ (Table 8) was observed only at the sites most favorable for disease (La Verrière and Le Rheu 1992). A positive correlation between plant density and parameter $c_{1}$ was observed only at the most favorable site, Le Rheu 1993 (Table 7). The influence of plant density on $c_{2}$ also was variable (Table 8). The effect of the rate of nitrogen fertilizer depended on the parameter: $\mathrm{c} 1$ was increased and c2 was decreased by high nitrogen (Tables 7 and 8), whereas both were reduced by ammonium fertilizer. The effect of straw treatment on $c_{1}$ and $c_{2}$ was not significant.

\section{DISCUSSION}

The effect of the experiment site on take-all was very important: if the site was not favorable to disease expression (e.g.,

TABLE 6. Mean values for equation parameters ${ }^{\mathrm{z}}$ associated with primary $\left(c_{1}\right)$ and secondary $\left(c_{2}\right)$ development of take-all on wheat over time

\begin{tabular}{lcccc}
\hline & \multicolumn{4}{c}{ Experiment site } \\
\cline { 2 - 5 } Parameter & $\begin{array}{c}\text { Le Rheu } \\
1992\end{array}$ & $\begin{array}{c}\text { Le Rheu } \\
1993\end{array}$ & La Verrière & Chartres \\
& $1.90 \times 10^{-4}$ & $2.97 \times 10^{-4}$ & $8.59 \times 10^{-5}$ & $1.74 \times 10^{-5}$ \\
$c_{1}$ & $2.32 \times 10^{-3}$ & $1.45 \times 10^{-3}$ & $2.73 \times 10^{-3}$ & $1.05 \times 10^{-4}$ \\
$c_{2}$ & \multicolumn{4}{c}{$y=\frac{1-e^{-\left(c_{1}+c_{2}\right) t}}{1+\left(c_{2} / c_{1}\right) e^{-\left(c_{1}+c_{2}\right) t}}$}
\end{tabular}

to disease incidence on different plots with time, where $y$ is the percentage of plants with take-all and $t$ is the sum of degree days since sowing. This equation was derived by integrating the equation $d y / d t=\left(k_{1} p+k_{2} n i\right)(1-y)$, where $n$ is the number of plants, $c_{1}=k_{1} p$, and $c_{2}=k_{2} n$. 
Chartres), take-all incidence stayed low even if all other factors favored its development. Site differences observed for final takeall incidence and primary infection were probably due to climate. Le Rheu is closer to the sea, and consequently, the humidity and temperature conditions are more favorable to take-all (19). Soil conduciveness to take-all and inoculum density are other factors that may have differed among the sites. Le Rheu 1992 and 1993 were the two sites where the two preceding crops were hosts. A higher amount of infectious primary inoculum at Le Rheu was confirmed by the potted plant assessment.

Sowing date was the cultural practice with the most important effect on disease. These observations are consistent with previous reports $(16,31,41)$. The disease increase on early sown plots is said to be caused by a longer period favorable for infection before winter. This explanation is probably true for the primary infection cycle (illustrated by parameter $c_{1}$ ) for which an important increase was observed on early sown plots. The secondary infection, however, takes place later and may only begin during the spring. In this case, secondary infection was not influenced by a longer prewinter infection period. Late sowing may result in a slightly longer postwinter period, which might explain the higher $c_{2}$ values for La Verrière with late sowing.

Plant density was important only at early stages at which the factor was usually positively correlated to take-all. This short-lived influence of high plant density might be explained by the shorter distance between soil inoculum and roots, which would increase the probability of contact between the fungus and its host. This inoculum-plant distance is very important because the fungus only spreads short distances by mycelial growth (30). Later, as roots begin to grow, the probability of contact with the fungus increases proportionally. A high root number per plant, therefore, increased early take-all. However, as soon as the root density became established through growth, it was no longer a limiting factor because the fungus could readily reach new host plants. Therefore, plant density no longer influenced disease. This might explain the rarity of reports of plant density influencing take-all (12).

The analysis of the $c_{1}$ and $c_{2}$ parameters from the disease progress model showed that early infections, i.e., primary infection and early secondary infections (illustrated by a parameter increase in early sowing at Le Rheu in 1992) were increased by high plant density. Intermediary secondary infections (illustrated by an absence of sowing date influence on $c_{2}$ at Le Rheu in 1993) were decreased by high plant density and increased by high root num-

TABLE 7. Regression estimates for the effect of wheat cultural practices on disease progress model parameter $c_{1}$, which is associated with primary takeall development on wheat ${ }^{\mathrm{v}}$

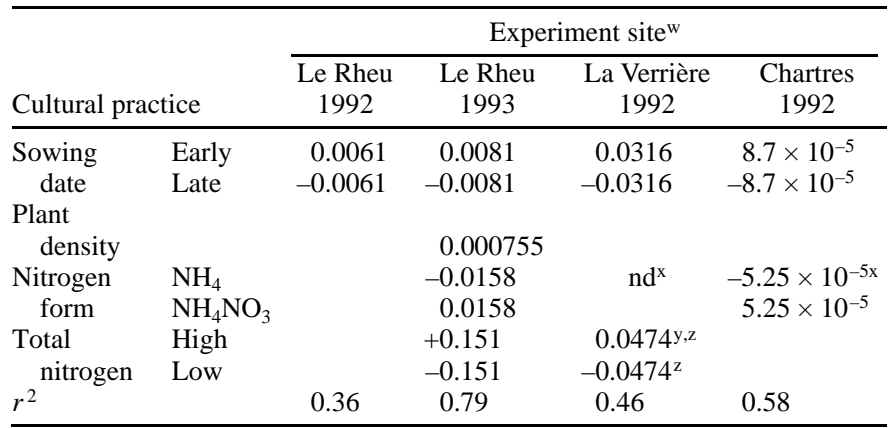

v Estimation of the effects of the experimental factors significant at $P=0.1$.

${ }^{w}$ For each site, a Box-Cox transformation was necessary. The transformations were $c_{1}{ }^{t}=\mathrm{c}_{1}{ }^{(1-1.96 / 2)}$ for Le Rheu 1992; $\mathrm{c}_{1}{ }^{t}=\mathrm{c}_{1}{ }^{(1-1.80 / 2)}$ for Le Rheu 1993; $c_{1}{ }^{t}=c_{1}{ }^{(1-1.74 / 2)}$ for La Verrière 1992; and $c_{1}{ }^{t}=\mathrm{c}_{1}{ }^{(1-0.49 / 2)}$ for Chartres 1992.

x There were no plots with $\mathrm{NH}_{4}$ on this site (nd = not determined).

y These effects were only significant at $P=0.11$ and 0.16 , respectively, but without their presence, no significant model would be possible.

${ }^{z}$ The sowing date-total nitrogen interaction was significant at $P=0.16$. The number estimates the effect of nitrogen on early sown plots. ber per plant. Late secondary infections, in contrast, were not influenced by plant density.

The effect of nitrogen dose is an important management consideration because high nitrogen may stimulate both the pathogen and its antagonistic microflora $(4,10)$ and, more specifically, antagonistic fluorescent pseudomonads that may need a prior takeall infection to develop $(33,34)$. The hypothesis developed by Sarniguet et al. $(33,34)$ is consistent with our results for high nitrogen dose: the increase in primary infection and in early takeall on seminal roots observed in our trials could be due to stimulation of G. graminis propagules in soil. According to this hypothesis, early infection would stimulate early fluorescent pseudomonad development, and the development would then be accentuated by high nitrogen. This increase in fluorescent pseudomonad populations would later interfere with pathogen expansion, explaining why secondary infection and take-all on nodal roots were limited considerably in high nitrogen plots in our trials. This late disease decrease also is consistent with other reports $(12,13,21)$.

Decreased take-all observed on plots with the ammonium form of fertilizer is consistent with previous reports $(8,18,21,24,27,33$, $34,37,38)$ that attribute this to antagonistic microflora $(24,33$, 34,37 ), i.e., fluorescent pseudomonads are stimulated by the ammonium form of nitrogen and, thus, limit disease development. Antagonist stimulation by ammonium was faster than stimulation by increasing nitrogen rate and limited both infection cycles. This difference between nitrogen dose and form effects might be explained by the dual effect of nitrogen dose on both pathogen and antagonists, whereas nitrogen form only seems to influence the latter. The effect of ammonium is still under discussion and also might act indirectly by decreasing $\mathrm{pH}$ (37) and increasing manganese availability $(20,26)$, which are known to have an impact on take-all $(20,22)$.

The removal or burial of cereal straw did not affect disease. These observations are consistent with numerous reports $(1,14,15$, 36 ). The presumed stimulation of inoculum survival or of antagonistic soil microflora by buried organic matter was not sufficient to influence disease development.

This study showed that hierarchy and interaction between the various factors were very important. Practices other than sowing

TABLE 8. Regression estimates for the effect of wheat cultural practices on disease progress model parameter $c_{2}$, which is associated with secondary take-all development on wheat ${ }^{\mathrm{V}}$

\begin{tabular}{|c|c|c|c|c|c|}
\hline \multirow{2}{*}{\multicolumn{2}{|c|}{ Cultural practice }} & \multicolumn{4}{|c|}{ Experiment site ${ }^{\mathrm{w}}$} \\
\hline & & $\begin{array}{c}\text { Le Rheu } \\
1992\end{array}$ & $\begin{array}{c}\text { Le Rheu } \\
1993\end{array}$ & $\begin{array}{c}\text { La Verrière } \\
1992\end{array}$ & $\begin{array}{c}\text { Chartres } \\
1992\end{array}$ \\
\hline \multirow{3}{*}{$\begin{array}{l}\text { Sowing } \\
\text { date } \\
\text { Plant } \\
\text { density }\end{array}$} & Early & $1.25 \times 10^{-3}$ & & $-2.67 \times 10^{-3}$ & \\
\hline & Late & $-1.25 \times 10^{-3}$ & & $2.67 \times 10^{-3}$ & \\
\hline & & $\begin{array}{l}1.32 \times 10^{-6} \\
1.59 \times 10^{-5 x}\end{array}$ & $-6.97 \times 10^{-7}$ & & \\
\hline $\begin{array}{l}\text { Nitrogen } \\
\text { form }\end{array}$ & $\begin{array}{l}\mathrm{NH}_{4} \\
\mathrm{NH}_{4} \mathrm{NO}_{3}\end{array}$ & $\begin{array}{r}-2.64 \times 10^{-4} \\
2.64 \times 10^{-4}\end{array}$ & & $\mathrm{nd}^{\mathrm{y}}$ & \\
\hline \multirow[t]{2}{*}{$\begin{array}{l}\text { Total } \\
\text { nitrogen }\end{array}$} & High & & & $\begin{array}{l}-7.1 \times 10^{-3} \\
-2.5 \times 10^{-4} \mathrm{z}\end{array}$ & \\
\hline & Low & & $3.7 \times 10^{-5}$ & $\begin{array}{l}7.1 \times 10^{-3} \\
2.5 \times 10^{-4 z}\end{array}$ & \\
\hline$r^{2}$ & & 0.52 & 0.34 & 0.50 & 0 \\
\hline
\end{tabular}

${ }^{v}$ Estimation of the effects of the experimental factors significant at $P=0.1$.

${ }_{w}$ For two sites, a Box-Cox transformation was necessary. The transformations were $c_{2}{ }^{t}=c_{2}{ }^{(1+0.89 / 2)}$ for Le Rheu 1993 and $c_{2}{ }^{t}=c_{2}{ }^{(1-0.57 / 2)}$ for La Verrière 1992 .

x The sowing date-plant density interaction was significant at $P=0.04$. The first number gives the regression estimate for the effect of plant density on disease in early sown plots; the second number is the estimate for late sown plots.

y There were no plots with $\mathrm{NH}_{4}$ on this site (nd = not determined).

z The sowing date-total nitrogen interaction was significant at $P=0.07$. The first number gives the regression estimate for the effect of plant density on disease in early sown plots; the second number is the estimate for late sown plots. 
date were usually significant only when sowing date effect also was significant. Sowing date, therefore, may be considered as the dominant factor and its interactions with the other practices the strongest. The influence of the other practices seldom depended on sowing date, but frequently seemed stronger on early sown plots. The type of interaction, therefore, strongly resembled the one between site and crop management, because several practices had a stronger influence or were only significant when the trial site was favorable to disease expression. Thus, each factor seemed to amplify the risk due to the other effects, and low effect factors could only influence disease if high effect factors also were favorable to its expression.

The effects of cultural practices on disease incidence and infection cycles could be estimated and classified with the equation used to model increase of take-all over time. The equation was less sophisticated than the one developed by Brassett and Gilligan $(3,11)$ that integrates root development and inoculum decay. However, their equation was not possible in this paper because too many parameters would have to be estimated on each plot. In contrast, Brassett and Gilligan $(3,11)$ fitted a single equation to data originating from several plots. They had more observations to estimate parameters but could not compare cropping systems. However, because the objective of our work was to classify cropping systems according to general disease evolution and not to model minor disease variations during the growing season, the simpler two-parameter equation was sufficient, as was shown for eyespot (7).

Our results contribute to the understanding of the relative importance of crop management practices to limit take-all expression. The factorial experiments and modeling results show that environment and cultural practices have important effects on this disease: cultural practices should not be considered individually; crop management must be reasoned as a whole with respect to hierarchy and interactions.

\section{ACKNOWLEDGMENTS}

This work was financed by the Grand-Duchy of Luxembourg and the Institut National de la Recherche Agronomique, France. We thank M. Cotten (INRA Rennes), B. Mille (INRA La Verrière), and H. Yvrard (Lycée agricole de Chartres) for conducting our field trials. We also thank the reviewers and the senior editor for their help in improving this paper.

\section{LITERATURE CITED}

1. Bodker, L., Schulz, H., and Kristensen, K. 1990. Influence of cultural practices on incidence of take-all (Gaeumannomyces graminis var. tritici) in winter wheat and winter rye. Tidsskr. Planteavl 94:201-209.

2. Box, G. E. P., Hunter, W. G., and Hunter, J. S. 1978. Statistics for Experimenters: An Introduction to Design, Data Analysis and Model Building. John Wiley \& Sons, New York.

3. Brassett, P. R., and Gilligan, C. A. 1989. Fitting of simple models for field disease progress data for the take-all fungus. Plant Pathol. 38:397-407.

4. Butler, F. C. 1959. Saprophytic behaviour of some cereal root rot fungi. IV. Saprophytic survival in soils of high and low fertility. Ann. Appl. Biol. 47:28-36.

5. Colbach, N., and Huet, P. 1995. Modelling the frequency and severity of root and foot diseases in winter wheat monocultures. Eur. J. Agron. 4: 217-227.

6. Colbach, N., Lucas, P., and Cavelier, N. 1994. Influence des successions culturales sur les maladies du pied et des racines du blé d'hiver. Agronomie 14:525-540

7. Colbach, N., and Meynard, J. M. 1995. Soil tillage and eyespot: Influence of crop residue distribution on disease development and infection cycles. Eur. J. Plant Pathol. 101:601-611.

8. Cook, R. J., and Rovira, A. D. 1976. The role of bacteria in the biological control of Gaeumannomyces graminis by suppressive soils. Soil Biol. Biochem. 8:269-273.

9. Garrett, S. D. 1940. Soil conditions and the take-all disease of wheat. V. Further experiments on the survival of Ophiobolus graminis in infected wheat stubble buried in the soil. Ann. Appl. Biol. 27:199-204.

10. Garrett, S. D. 1970. Pathogenic Root-Infecting Fungi. Cambridge University Press, Cambridge.
11. Gilligan, C. A., and Brassett, P. R. 1990. Modelling and estimation of the relative potential for infection of winter wheat by inoculum of Gaeumannomyces graminis derived from propagules and infected roots. J. Phytopathol. 129:58-68.

12. Glynne, M. D. 1951. Effect of cultural treatments on wheat and on the incidence of eyespot lodging, take-all and weeds. Ann. Appl. Biol. 38: 665-688.

13. Glynne, M. D., and Slope, D. B. 1959. Effects of previous wheat crops, seed rate and nitrogen on eyespot, take-all, weeds and yields of two varieties of winter wheat. Ann. Appl. Biol. 47:187-199.

14. Herman, M. 1985. Zhoknoceni vlievu zeleneho hnojeni a zaolani slamy na choroby pat stebel obilnin (An evaluation of the effect of green manuring on the rot in cereals). Sb. Uvtiz. Ochr. Rostl. 21:81-87.

15. Höflich, G., Steinbrenner, K., and Roth, R. 1977. Wirkungen verschiedener Maßnahmen der organischen und mineralischen Düngung, der Bodenbearbeitung und der Beregnung auf den Befall des Getreides mit Fußkrankheiten. Arch. Acker-Pflanzenbau. Bodenkd. 21:733-747.

16. Hornby, D., Bateman, G. L., Gutteridge, R. J., Lucas, P., Montfort, F., and Cavelier, A. 1990. Experiments in England and France on fertilisers, fungicides and agronomic practices to decrease take-all. Pages 771-776 in: Proceedings of the Brighton Crop Protection Conference.

17. Hornby, D., and Fitt, B. D. L. 1981. Effect of root-infecting fungi on structure and function of cereal roots. Pages 101-103 in: Effects of Disease on the Physiology of the Growing Plant. P. G. Ayres, ed. Cambridge University Press, Cambridge.

18. Hornby, D., and Goring, C. A. I. 1972. Effects of ammonium and nitrate nutrition on take-all disease on wheat in pots. Ann. Appl. Biol. 70:225231.

19. Huber, D. M. 1981. The role of nutrients and chemicals. Pages 317-341 in: Biology and Control of Take-All. M. J. C. Asher and P. J. Shipton, eds. Academic Press, London.

20. Huber, D. M., and McCay-Buis, T. S. 1993. A multiple component analysis of the take-all disease of cereals. Plant Dis. 77:437-447.

21. Huber, D. M., Painter, C. C., McKay, H. C., and Peterson, D. L. 1968. Effect of nitrogen fertilization on take-all of winter wheat. Phytopathology 58:1470-1472.

22. Huber, D. M., and Wilhelm, N. S. 1988. The role of manganese in disease resistance. Pages 155-173 in: Manganese in Soils and Plants. R. D. Graham, R. J. Hannam, and N. C. Uren, eds. Kluwer Academic Publishers, Dordrecht, Netherlands.

23. Leterme, P., Manichon, H., and Roger-Estrade, R. 1994. Analyse intégrée des rendements du blé tendre et leurs causes de variation dans un réseau de parcelles d'agriculteurs du Thymerais. Agronomie 14:341-361.

24. Lucas, P., and Collet, J. M. 1987. Influence de la fertilisation azotée sur la réceptivité d'un sol au piétin-échaudage, le développement de la maladie au champ et les populations de Pseudomonas fluorescents. Bull. OEPP 18:103-111.

25. Lucas, P., Montfort, F., Cavelier, N., and Cavelier, A. 1986. Attempts to combine different methods of control of foot and root diseases of winter wheat. Pages 237-249 in: Integrated Crop Protection in Cereals. R. Carralloro and K. D. Sunderland, eds. Balkema, Rotterdam, Netherlands.

26. Lucas, P., and Sarniguet, A. 1990. Soil receptivity to take-all: Influence of some cultural practices and soil chemical characteristics. Symbiosis 9:51-57.

27. MacNish, G. C., and Speijers, J. 1982. The use of ammonium fertilizers to reduce severity of take-all (Gaeumannomyces graminis var. tritici) on wheat in western Australia. Ann. Appl. Biol. 100:83-90.

28. Nilsson, H. E. 1969. Studies of root and foot rot diseases of cereals and grasses. I. On resistance to Ophiobolus graminis Sacc. Lantbrukshägsklans Annabr. 35:275-307.

29. Polley, R. W., and Thomas, M. R. 1991. Surveys of diseases of winter wheat in England and Wales (1976-1988). Ann. Appl. Biol. 119:1-20.

30. Prew, R. D. 1977. Studies of the spread, survival and control of take-all and other foot and root disease of wheat and barley. Ph.D. thesis. University of London, London.

31. Prew, R. D., Beane, J., Carter, N., Church, B. M., Dewar, A. M., Lacey, J., Penny, A., Plumb, R. T., Thorme, G. N., and Todd, A. D. 1986. Some factors affecting the growth and yield of winter wheat grown as a third cereal with much or negligible take-all. J. Agric. Sci. Cambridge 107: 639-671.

32. Rémy, J. C., and Hébert, J. 1977. Le devenir des engrais azotés dans le sol. C.R. Acad. Agric. Fr. 63:700-710.

33. Sarniguet, A., Lucas, P., and Lucas, M. 1992. Relationships between takeall, soil conduciveness to the disease, populations of fluorescent pseudomonads and nitrogen fertilizer. Plant Soil 145:17-27.

34. Sarniguet, A., Lucas, P., and Lucas, M. 1992. Soil conduciveness to take-all of wheat: Influence of the nitrogen fertilizers on the structure of populations of fluorescent pseudomonads. Plant Soil 145: 29-36

35. SAS Institute. 1989. SAS/STAT User's Guide. Version 6. 4th ed. SAS In- 
stitute, Cary, NC.

36. Shipton, P. J. 1972. Influence of stubble treatment and autumn application of nitrogen to stubbles on the subsequent incidence of take-all and eyespot. Plant Pathol. 21:147-155.

37. Smiley, R. W. 1978. Colonization of wheat roots by Gaeumannomyces graminis inhibited by specific soils, microorganisms and ammoniumnitrogen. Soil Biol. Biochem. 10:175-179.

38. Smiley, R. W., and Cook, R. J. 1973. Relationship between take-all of wheat and rhizosphere $\mathrm{pH}$ in soils fertilized with ammonium vs. nitrate nitrogen. Phytopathology 63:882-889.

39. Steinbrenner, K., and Höflich, G. 1977. Zur Schadwirkung der Getreidefußkrankheit Cercosporella herpotrichoides Fron und Ophiobolus graminis Sacc. Arch. Acker-Pflanzenbau. Bodenkd. 21:61-71.

40. Steinbrenner, K., and Höflich, G. 1980. Bedeutung bodenbürtiger Ge- treidefußkrankheitserreger in spezialisierten Getreidefruchtfolgen und Möglickeiten zu iurer Bekämpfung. Tag.-Ber. Akad. Landwirtsch.-Wiss. DDR (Berl.) 181:29-36.

41. Steinbrenner, K., and Höflich, G. 1984. Einfluß acker- und pflanzenbaulicher Maßnahmen auf den Befall des Getreides durch Pseudocercosporella herpotrichoides (Fron) Deighton und Gaeumannomyces graminis (Sacc.) Arx et Olivier. Arch. Acker-Pflanzenbau. Bodenkd. 20:469-486.

42. Walker, A. G. 1967. Intensive cereal growing and disease control. Agriculture 74:171-175

43. Werker, A. R., and Gilligan, C. A. 1990. Analysis of the effects of selected agronomic factors on the dynamics of the take-all disease of wheat in field plots. Plant Pathol. 39:161-177.

44. Zadoks, J. C., Chang, T. T., and Konzak, C. F. 1974. A decimal code for the growth stages of cereals. Weed Res. 14:415-421. 